Florida International University FIU Digital Commons

7-2-2015

\title{
The Effects of Fire on Spore Viability of Lygodium microphyllum (Old World Climbing Fern)
}

Nicole Sebesta

Florida International University, nsebe001@fiu.edu

DOI: $10.25148 /$ etd.FIDC000096

Follow this and additional works at: https:// digitalcommons.fiu.edu/etd

Part of the Biology Commons, Botany Commons, $\underline{\text { Plant Biology Commons, and the Weed }}$ Science Commons

\section{Recommended Citation}

Sebesta, Nicole, "The Effects of Fire on Spore Viability of Lygodium microphyllum (Old World Climbing Fern)" (2015). FIU Electronic Theses and Dissertations. 2203.

https://digitalcommons.fiu.edu/etd/2203 


\title{
FLORIDA INTERNATIONAL UNIVERSITY \\ Miami, Florida
}

THE EFFECTS OF FIRE ON SPORE VIABILITY OF

\section{LYGODIUM MICROPHYLLUM (OLD WORLD CLIMBING FERN)}

\author{
A thesis submitted in partial fulfillment \\ of the requirements for the degree of \\ MASTER OF SCIENCE \\ in \\ BIOLOGY \\ by
}

Nicole Sebesta

2015 
To: Dean Michael R. Heithaus

College of Arts and Sciences

This thesis, written by Nicole Sebesta, and entitled The Effects of Fire on Spore Viability of Lygodium microphyllum (Old World Climbing Fern), having been approved in respect to style and intellectual content, is referred to you for judgment.

We have read this thesis and recommend that it be approved.

Suzanne Koptur

Michael Ross

$\overline{\text { Jennifer H. Richards, Major Professor }}$

Date of Defense: July 2, 2015

The thesis of Nicole Sebesta is approved.

Dean Michael R. Heithaus College of Arts and Sciences

Dean Lakshmi N. Reddi University Graduate School

Florida International University, 2015 


\section{DEDICATION}

I dedicate this thesis to my parents, Marina and Duane, whose love, comedic encouragement, and patience contributed greatly to my graduate experience. I further dedicate this thesis to my uncle, Rafael Repetto, who is partially at fault for my fascination with nature, respect for science, and my insufficient fear of snakes. My former employer-turned-friend, the late John S. Frost, whose love of nature and, in particular, the Southern Leopard frog (Lithobates sphenocephalus), inspired me more than he knew. 


\section{ACKNOWLEDGMENTS}

I wish to thank my major professor, Dr. Jennifer H. Richards, for her support, patient encouragement, guidance, and humor. I am extremely grateful for the various advisements she has provided and for sharing with me her research plans on the ideal plant, both ferny and viny, for my interests. My other committee members, Dr. Suzanne Koptur and Dr. Michael Ross, have provided me with invaluable suggestions, resources and encouragement. Dr. Steve Oberbauer provided guidance and research equipment, as did Dr. Evelyn Gaiser.

Dr. Sonja Montas-Hunter and Dr. Shekhar Bhansali provided much support, as well as excellent feedback, on proposals and statements. I thank them for giving me the opportunity to attend graduate school with full financial support via the Louis Stokes Alliance for Minority Participation Bridge to Doctorate program. This NSF fellowship (award no. 1301998) undoubtedly facilitated my completing this master's within two years. This research was additionally funded by Everglades National Park, CESI \#P12AC11125.

Many thanks also for the graduate life advice and research help provided by Lorenzo Menzel, Franco Tobias. 


\title{
ABSTRACT OF THE THESIS \\ THE EFFECTS OF FIRE ON SPORE VIABILITY OF LYGODIUM MICROPHYLLUM (OLD WORLD CLIMBING FERN)
}

\author{
by
}

Nicole Sebesta

Florida International University, 2015

Miami, Florida

Professor Jennifer H. Richards, Major Professor

Lygodium microphyllum, native to the Old World tropics, has invaded central and southern Florida, destroying native habitats, reducing biodiversity and altering fire regimes. Prescribed fire, one of several methods used to manage L. microphyllum infestations, reduces fern biomass over large areas, but its effects on spore viability are unknown. To provide tools to evaluate whether fire-dispersed spores are viable, this research determined how heat affects spore viability. Spores were exposed to temperatures of $50^{\circ} \mathrm{C}$ to $300^{\circ} \mathrm{C}$ for durations of 5 seconds to 1 hour, then allowed to germinate on agar in petri plates. Percent germination was assayed after two weeks. Temperatures of $50^{\circ} \mathrm{C}$ had little effect; $300^{\circ} \mathrm{C}$ killed spores for all durations. Results indicate that while viability of unburnt spores decreases with increasing temperature and duration of heat exposure, spores are killed when exposed to relatively low temperatures compared to those in fires. 


\section{TABLE OF CONTENTS}

CHAPTER

PAGE

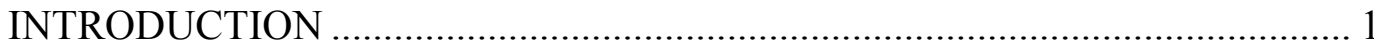

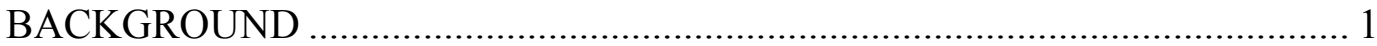

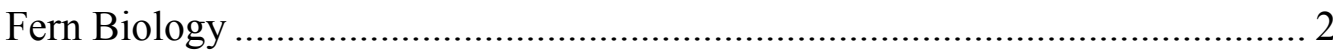

Invasive Species Characteristics ........................................................... 5

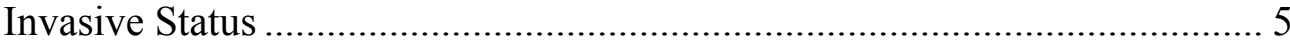

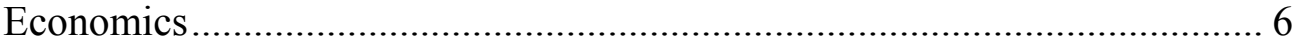

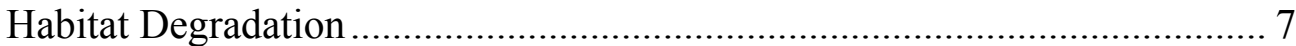

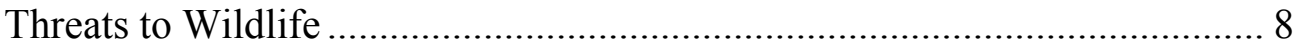

Alteration of Natural Fire Regimes............................................................. 9

Management and Control Tools ................................................................... 10

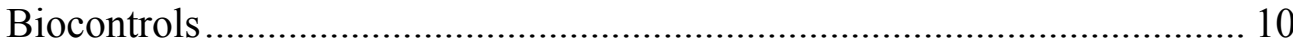

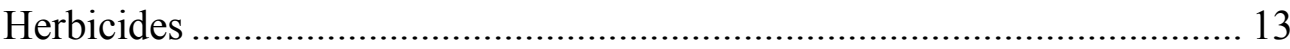

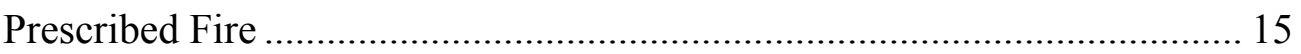

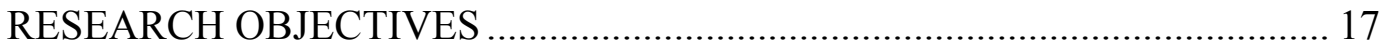

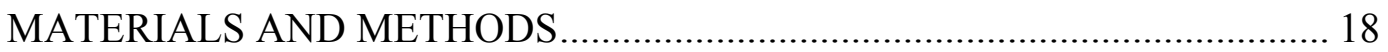

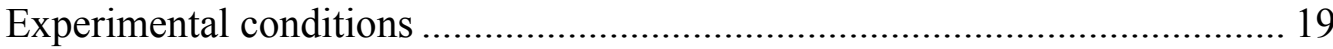

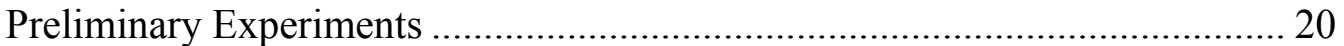

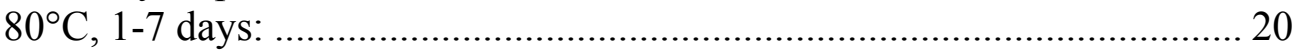

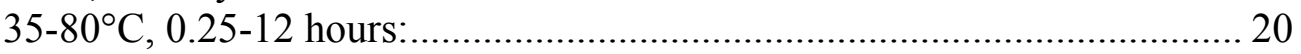

35-65 ${ }^{\circ} \mathrm{C}, 5-25$ minutes:

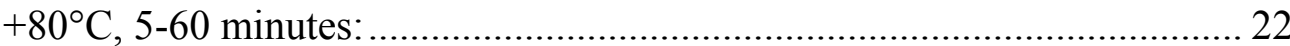

Spore soak times: ............................................................................... 22

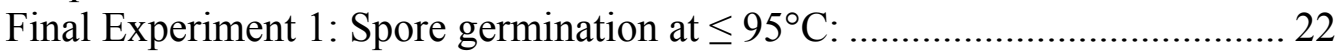

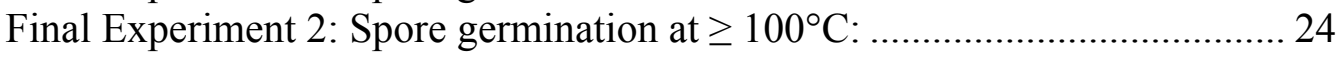

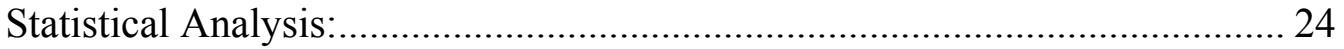

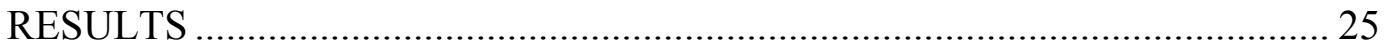

Preliminary Experiments .................................................................... 25

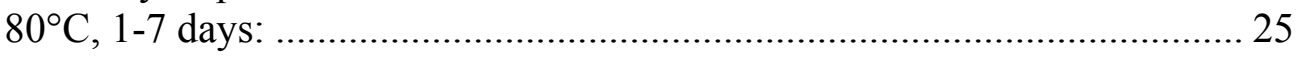

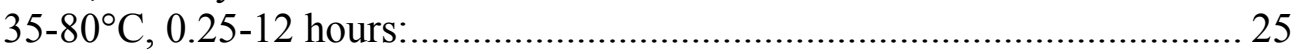

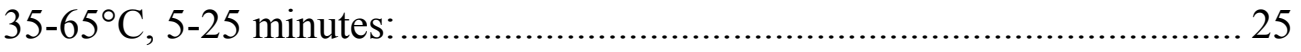

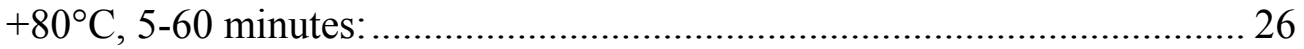

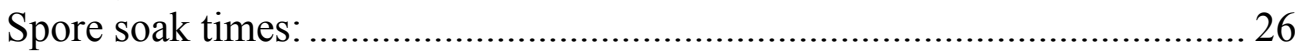

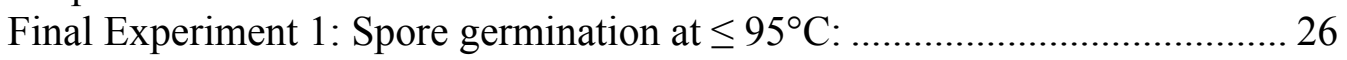

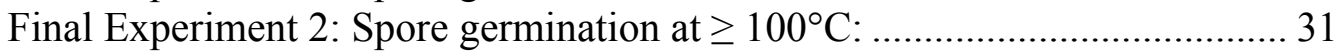

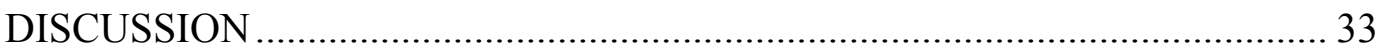

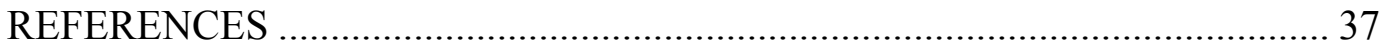


APPENDIX 


\section{INTRODUCTION}

Old World Climbing Fern (Lygodium microphyllum (Cav.) R. Br.), native to the subtropics of Africa, Asia, and Australia, has become a major invasive exotic species in central and southern Florida. Since its introduction to Palm Beach in the late 1950s (Beckner 1968, Pemberton and Ferriter 1998), L. microphyllum has infested more than 49,000 hectares of central and southern Florida, forming dense rachis mats that smother native vegetation, damage natural habitats and alter fire regimes (Ferriter and Pernas 2006, Lott et al. 2003, Stocker et al. 2008). In the invaded range it is found in both wetlands and uplands, including sawgrass marshes, pinelands, hardwood hammocks, cypress stands, bayheads, and mangrove communities (Pemberton and Ferriter 1998). The fern has been designated one of Florida's most serious invasive species by the Florida Exotic Pest Plant Council (FLEPPC) because of the severe ecological damage it has caused, which even threatens the success of Everglades restoration (Hutchinson et al. 2006).

Prescribed fire is one of several methods currently used to manage $L$. microphyllum infestations. However, as the species is still spreading rapidly and infestations in the Cape Sable area of southwest Everglades National Park (ENP) are expanding (Rodgers et al. 2014), efforts to manage and control L. microphyllum need refinement.

\section{BACKGROUND}

Successful management of L. microphyllum depends on understanding three components: fern biology, invasive species characteristics, and management and control tools including prescribed fire. 


\section{Fern Biology}

Although occasionally regarded as the only genus within the family Lygodiaceae (Nelson 2000, Smith et al. 2006, Vasco et al. 2013), Lygodium is more commonly treated as a genus within the family Schizaeaceae (Beckner 1968; Gandolfo et al. 2000; Lott et el. 2003; Madeira et al. 2008; Mueller 1982a, b, 1983; Pemberton 1998; Wikström et al. 2002). Recently, Christenhusz and Chase (2014) have reaffirmed its placement in Schizaeaceae on the basis of molecular phylogenetic analyses and suggest that Lygodium could comprise its own subfamily Lygodioideae Christenh., as sister to subfamilies Schizaeoideae Lindl., and Anemioideae C.Presl. Lygodium is a primitive genus characterized by distinct morphology including typically lobed fertile pinnulules (Gandolfo et al. 2000). The genus was present in North America and Germany by the Late Cretaceous (Gandolfo et al. 2000) and had substantial representation throughout the Cenozoic Era (Wikström et al. 2002). Although considered a primitive fern, its extremely modified vegetative morphology indicates later functional specialization of the shoot, which is clearly differentiated into leaves and stem, as are seed plants, but in Lygodium the leaf takes on characteristics of the shoot in seed plants (Mueller 1982a). Earlier accounts of L. microphyllum sometimes referred to it as Lygodium scandens (L.) Swartz or Ugena microphylla Cav., and during the height of its importation and sale, it was apparently often confused with and sold as Japanese Climbing Fern (Lygodium japonicum (Thunb.) Sw.), another exotic congeneric fern that has invaded central and northern Florida (Beckner 1968; Ferriter 2001, Hutchinson et al. 2006). Although $L$. microphyllum and L. japonicum are closely related and morphologically similar, differences include pinnule shape, rhizome depth, and rhizome tolerance to freezing 
temperatures; L. japonicum's greater cold tolerance likely contributes to its current successful invasion of colder northern Florida (Hutchinson and Langeland 2014, Mueller 1982a, Van Loan 2006). In contrast to L. japonicum, the viability of L. microphyllum spores and gametophytes is greatly reduced by exposure to freezing temperatures, as shown by Hutchinson and Langeland (2014), possibly limiting its northward expansion. Lygodium microphyllum is a homosporous fern composed of a dichotomously branching, protostelic rhizome with adventitious roots and indeterminate climbing leaves (fronds) (Mueller 1982a). The rhizome grows at, or just below, the soil surface and, once established, can withstand temporary inundation and variable water levels (Gandiaga et al. 2009, Mueller 1982a, Volin et al. 2004). Leaves form dorsally on the rhizome, follow a single rank, and develop from a single cell produced by the apical meristem (Mueller 1982a). The primary leaves are determinate and usually less than $10 \mathrm{~cm}$ in height, while secondary leaves are indeterminate and twining, sometimes reaching over $30 \mathrm{~m}$ in length (Mueller 1982a). The climbing fronds of L. microphyllum are analogous to twining shoots in angiosperms in four ways: indeterminate growth, circumnutation that is characteristic of twiners, delayed expansion of pinnae, and presence of a resting leafbud on each pinna (Mueller 1982a). This unusual morphology contributes to the characteristic and easily recognizable climbing habit of L. microphyllum.

Climbing leaves have alternate pinnae, each possessing opposite pinnules and a resting leaf bud, which can resume indeterminate growth should the leaf apex become damaged (Mueller 1982a, 1983). Pinnae are dimorphic, although both fertile and sterile pinnae may occur on the same climbing leaf. Subdivisions of pinnules (pinnulules) are usually unlobed if sterile but fertile pinnulules will form sorophores of enrolled leaf 
margins (Gandolfo et al. 2000) that bear sporangia on the abaxial surface. A typical pinnulule may produce more than 28,000 spores, which are wind-dispersed and can be produced throughout the year (Volin 2004). Lygodium microphyllum spores are achlorophyllous and are reported to maintain their viability for four years (Stocker et al. 2008). The spores of L. microphyllum have a characteristically reticulate surface and are large, averaging $65 \mu \mathrm{m}$, compared to most fern spores, which range from 45-55 $\mu \mathrm{m}$ (Moran 2004, Tryon and Lugardon 1991).

Lygodium microphyllum reproduces sexually by three modes: intergametophytic crossing (eggs produced from one spore, sperm produced from a spore from a genetically distinct sporophyte), intergametophytic selfing (eggs and sperm produced from two spores that came from the same sporophyte), and intragametophytic selfing (eggs and sperm produced from a single spore) (Lott et al. 2003). The fern's life cycle includes alternation of generations consisting of a diploid sporophyte and a haploid gametophyte, which are independent except during the development of the embryo and the initial establishment of the young sporophyte, both of which are dependent upon the gametophyte. Through asynchronous gametophyte maturation, the first gametophyte to mature is female and may produce antheridiogens, which are chemical signals that force neighboring, young gametophytes to develop as males, producing sperm and promoting outcrossing (Lott et al., 2003). In the absence of neighbors, however, antheridia and thus sperm will develop on the female gametophyte, forming a hermaphroditic gametophyte capable of intragametophytic selfing and giving rise to a diploid sporophyte from a single spore (Lott et al., 2003). Intragametophytic selfing likely contributes greatly to $L$. microphyllum's long-range dispersal and colonization ability (de Groot et al., 2012), 
while subsequent outcrossing as the population becomes established may be responsible for developing (or maintaining) high genetic diversity (Lott et al. 2003, Soltis and Soltis 1992). Mixed mating systems such as that found in L. microphyllum are not rare,

although the high rates of both intragametophytic selfing and outcrossing are very uncommon (Soltis and Soltis 1992).

\section{Invasive Species Characteristics}

\section{Invasive Status}

Florida, because of its subtropical climate, location, disturbance (altered hydrology, hurricanes, urban and suburban development) and its residents' propensity for horticultural and ornamental importations, is particularly plagued by hundreds of invasive plant species (OTA 1993, Pimentel et al. 2005). The FLEPPC tracks and ranks Florida's invasive plants and develops management plans. It has designated two categories of invasive severity, both of which cover spreading invasive exotic plants. Category I is the more severe of the two, listing plants that are causing ecological damage, "altering the native plant communities by displacing native species, changing community structures or ecological functions or by hybridizing with natives." Lygodium microphyllum is Category I by the first two criteria (Hutchinson et al. 2006).

Typical traits associated with invasive species include fast growth rate, exceptional propagule pressure, and tolerance of variable habitat conditions (Jose et al. 2013), all of which characterize L. microphyllum. Only a decade after its introduction, the fern caught the attention of John Beckner (1968), who noted, "It will be interesting to watch the future spread and behavior of Lygodium microphyllum in Florida." Just another ten years later, the fern was observed by Nauman and Austin (1978) to be smothering 
native vegetation, both shrubby and herbaceous. In keeping with its ruderal qualities, $L$. microphyllum is an opportunist, taking advantage of hurricane disturbances for spread and colonization. Lynch et al. (2009) showed increased L. microphyllum colonization of hurricane-caused gaps in tree islands in Loxahatchee National Wildlife Refuge. Among the gaps, recruitment was five times higher with the presence of water than without (Lynch et al. 2009). Although aided by disturbance, the spores readily establish in undisturbed habitats, including areas particularly difficult for managers to access, which drives up management costs (Hutchinson et al. 2006).

\section{Economics}

The U. S. has footed the bill for billions of dollars in costs associated with lost productivity (crops, forage, timber products, competition with desired species, etc.) and expenditures on management (herbicides, mechanical removal, extra veterinary care for livestock) of both plant and animal invasive species nationwide (Jose et al 2013, OTA 1993, Pimentel 2005). Depending on the inclusion of indirect and direct costs of invasive species (plant, animal, microorganism), estimates of the total combined costs to the U.S. economy exceed $\$ 100$ billion per year (Pimentel et al. 2000, Pimentel et al. 2005). Costs are estimated considering the losses of biodiversity, loss of habitat for endemic species (and subsequently reduced recreational tourism), changes to nutrient cycling, and reduction of climate regulating ability that accompany severe invasions of invasive exotic plant species (de Groot et al. 2002, Jose et al. 2013). In Florida, critical ecosystem functions like water filtration and aquifer replenishment provided by the Everglades wetland ecosystem are hindered by invasive plants (de Groot et al. 2002). 
Various departments and agencies spend thousands of dollars on control efforts, which include prevention, removal, treatment or containment, depending on the circumstances. Although the costs are high, the costs that would result from lost ecosystem function, degraded systems, lost biodiversity, etc. would be many times greater than control costs (Simberloff 2013). The Bureau of Invasive Plant Management (BIPM), a part of the Florida Department of Environmental Protection, funds and coordinates projects for controlling invasive plants on public lands and waterways (Hutchinson et al. 2006). Over a decade ago in 2003, BIPM spent nearly $\$ 6$ million on projects addressing L. microphyllum and L. japonicum and providing herbicides to land managers. The Florida Turnpike Enterprise, Loxahatchee National Wildlife Refuge and Jonathan Dickinson State Park together spent over \$1.5 million between 2002 and 2004 on L. microphyllum management alone (Hutchinson et al. 2006). During the 2009 fiscal year, the SFWMD spent over $\$ 1.4$ million on L. microphyllum management just for the following projects: Lake Okeechobee, Kissimmee Basin, Big Cypress, Greater Everglades, Northern Estuaries East, Northern Estuaries West, and System-Wide Biological Control (Rodgers et al. 2010). In fiscal year 2013, the District spent over $\$ 19$ million on invasive plant prevention, control and management and of this, $\$ 291,496$ was spent directly managing L. microphyllum (Rodgers et al. 2014).

\section{Habitat Degradation}

Lygodium microphyllum thrives in a variety of habitats, including mesic forests, cypress domes, pine flatwoods, sawgrass marshes, and tree islands — both disturbed and pristine natural areas (Hutchinson et al. 2006, Pemberton and Ferriter 1998). Sporophytes have been found to establish just above the level of inundation on the trunks of trees, 
stumps, rotting logs, the knees of cypress (Taxodium distichum), and even within tussocks of sawgrass (Cladium jamaicense) and native ferns (Ferriter 2001, Hutchinson and Langeland 2010). As the sporophyte matures, new fronds twine up older rachises, using them as support and forming an ever-thickening rachis mat. Such mats have been observed to be a meter thick in heavily infested areas, shading out native vegetation and physically preventing herbaceous and woody natives from reestablishing (Lott et al. 2003). Previously, the main mechanisms assumed to account for L. microphyllum's success in displacing native vegetation were physical smothering and shading (Pemberton and Ferriter 1998, Lott et al. 2003); however, allelopathy may also contribute to $L$. microphyllum's ability to out-competite natives, as shown by Wang et al. (2014) on several herbaceous plant species.

Many endangered native plant species are threatened by L. microphyllum, including curlygrass fern (Actinostachys pennula), Wright's pineland fern (Anemia wrightii Baker), as well as rare bromeliads such as Tillandsia fasciculata (Call et al. 2007, Ferriter 2001, Mehltreter et al. 2010, Nelson 2000). Other endemic species threatened by L. microphyllum infestations include giant leather fern (Acrostichum danaeifolium), thinned-leaved vanilla orchid (Vanilla mexicana), Okeechobee gourd (Cucurbita okeechobeensis), Garber's spurge (Chamaesyce garberi), and Dutchman's pipe (Aristolochia tomentosa) (Hutchinson et al. 2006, Mehltreter et al. 2010).

\section{Threats to Wildlife}

Native plants provide forage, nesting materials, hunting grounds and cover for wildlife. The invasion by L. microphyllum leads not to the mere addition of an exotic plant species to the array of natives, but to the elimination of nearly all native plant 
species on which Florida wildlife depend for survival. Among these degraded habitats are pinelands, which provide critical habitat for the endangered Florida panther (Puma concolor coryi), and freshwater marshes, lakes and cypress stands, which support the federally endangered snail kite (Rostrhamus sociabilis) (Ferriter 2001, Hutchinson et al. 2006).

Thus far, no Florida native animals have expanded their diets to include $L$. microphyllum fronds, spores or rhizomes (Smith et al. 2014). The fern provides no nectar and the persistent rachises remain impenetrably matted, flexible and surprisingly strong even in death, as after treatment with herbicides. Except for perhaps minor leaflet litter, L. microphyllum provides no alternative food source nor nesting materials. Lygodium microphyllum even poses direct danger to native wildlife by its growth habit. Wading birds, tortoises and mammals as large as deer have been found tangled (and deadpresumably by exhaustion or starvation) in the rachis mats (Darby and McKercher 2002, Frank Mazzotti pers. comm. 2015, Hutchinson 2006, Spear 2008).

\section{Alteration of Natural Fire Regimes}

Lygodium microphyllum affects the natural fire regime of habitats that it invades. The pine rocklands of south Florida normally have a two-layer vegetation structure composed of a primarily herbaceous, low stature understory of less than a few meters, and an upper story of pine canopy towering above. Here, as in pine flatlands, fire will burn through the understory eliminating intruding woody shrub seedlings, reducing needle and grass fuel and otherwise maintaining the habitat. Mature pine trees have thick protective bark that resists damage by these low fires, and the sensitive meristematic tissues and propagules are protected either at ground level (as in the young pine seedling 
grass stage) or high in the canopy above the heat and flames (Whelan 1995). However, when invaded by L. microphyllum, the two layers can become linked by the twining, climbing habit of the fern, which produces vertical rachis mats of hot-burning fine fuel that drape over shrubs and extend up the trunks of trees. These mats easily carry fire up to the forest canopy, often resulting in tree and seed death (Osborne et al. 2010, Pemberton and Ferriter 1998).

Cypress stands and hardwood hammocks, which are not fire-adapted, also suffer extensive damage when L. microphyllum creeps in from neighboring sawgrass marshes, bridging the normal firebreak of water and facilitating fire spread into the island (Clark 2002). As a result of the fine rachises and matted form, L. microphyllum burns relatively hot and fast. Hutchinson and Langeland (2010) suggest that because spores contain oils (lipid food reserves (Moran 2004)), they are ignitable and may contribute to the overall flammability of L. microphyllum and the subsequent fire damage.

\section{Management and Control Tools}

There are currently three major management treatments for L. microphyllum: biological controls, herbicides, and prescribed fire, each with benefits and drawbacks. While there is perhaps the most long-term promise for biocontrols (Mehltreter et al. 2010), in the interim every available method is needed to prevent the fern from irreparably harming the Everglades. Current trends in control are moving toward combined methods, as L. microphyllum is proving to be formidable.

\section{Biocontrols}

Biological control agents are typically insects or diseases that can be applied to infestations in the invaded range. Ideally, these biocontrols have a narrow host range, are 
highly specific to the target plant, and choose to starve to death rather than utilize a related (non-target) host plant (Pemberton 1998). Once established, biocontrols are selfpropagating and thus inexpensive, and can be excellent for fire-sensitive areas. However, they may also adapt or evolve to affect non-target species, and their use may be controversial, as it involves importing additional exotic species (Goolsby et al. 2006, Pemberton 1998, Simberloff 2013).

Considering the many previous disastrous introductions (Simberloff 2013), strict protocols are now required before introducing an exotic pest in efforts to control an invasive exotic plant. Through extensive surveys of L. microphyllum's native range and testing of potential biocontrols for specificity, a few candidates have been selected for further studies to determine their suitability for release in the invaded range (Goolsby 2003, Pemberton 1998). Closely related species that are of particular concern regarding hungry biocontrols for L. microphyllum include the native Lygodium palmatum (Bernh.) Sw. (Madeira et al. 2008), although its range is farther north, and Anemia wrightii, an endangered fern endemic to southern Florida.

Lygodium microphyllum has a very large native range, spanning much of the Old World tropics and subtropics. Surveys for suitable biocontrols were conducted in several areas of Australia after genetic work revealed that the L. microphyllum geographic haplotype plaguing central and southern Florida matched L. microphyllum populations in the Queensland area (Goolsby et al. 2006). Several potential biological matches found in the native Queensland range have been approved for test releases in the invaded range and are demonstrating encouraging results. Two of these approved biocontrols, a moth 
and a mite, are currently in use in southern Florida. A third potential biocontrol is described, but has yet to be released.

One successful biocontrol is the brown Lygodium defoliating moth, Neomusotima conspurcatalis Warren (Lepidoptera: Crambidae) which was released in multiple locations, including Jonathan Dickinson State Park, Loxahatchee National Wildlife Refuge, and Everglades National Park, between 2008 and 2010 (Smith et al. 2014). Considerable damage to L. microphyllum infestations was seen in Jonathan Dickinson State Park within the first year, and by 2012, swaths of damage were seen again in Jonathan Dickinson State Park and Loxahatchee National Wildlife Refuge, as well as the Barber Swamp Conservation Area. After 5 years, N. conspurcatalis is established and successfully controlling some L. microphyllum infestations (Smith et al. 2014).

The other biocontrol currently in use is the Lygodium leaf-galling mite, Floracarus perrepae Knihinicki and Boczek (Acariformes: Eriophyidae). This herbivorous mite is wind-dispersed and, following initial releases in Jonathan Dickinson State Park, Grassy Waters Preserve, and Loxahatchee in 2008, new colonies were found north and west of Jonathan Dickinson State Park in March 2013 (Lake et al. 2014). In May 2013, thriving populations of the mite were found on L. microphyllum infestations in Cape Sable, Everglades National Park, indicating a broad and expanding range of this biocontrol agent. In 2014, an additional site in southwest Florida and another site in ENP (February 2015) were found to contain F. perrepae (Ellen Lake and Melissa Smith, unpublished data).

A rust, Puccinia lygodii, is still under investigation as a potential third biocontrol of L. microphyllum on the basis of damage observed to L. japonicum. Preliminary 
experiments showed infective promise, but more research on the use of the rust is needed (Rayamajhi et al. 2005). Puccinia lygodii may also be useful as a secondary treatment, for example, following prescribed burning.

\section{Herbicides}

Herbicides can be highly selective and suitable for use in urban or fire-sensitive areas, or in combination with fire. Use of herbicides is more expensive than both biocontrol and prescribed fire, and ranges from $\$ 99-1730$ per hectare $(\$ 40-700$ per acre), depending on location and whether herbicide application is manual or aerial. Manual (ground application) tends to be more expensive and labor intensive; however, aerial application tends to damage more non-target species (Hutchinson et al. 2006).

A year after an apparently successful herbicide-only treatment in Bird Rookery Swamp, a massive germination event of spores occurred, indicating that herbicides alone do not inhibit spores. Reportedly thousands of sporelings were found growing on the "moist collar zone" of swamp trees, cypress knees and floating logs (Ferriter 2001). While herbicides can be effective in top-killing the fern, multiple applications may be required in order to eradicate a L. microphyllum infestation. Hutchinson et al. (2010) showed differential absorption and translocation of three herbicides (triclopyr, glyphosate and metsulfuron) into L. microphyllum sporophytes and related them to methods of application. Even using the most effective method (cut-and-spray), horizontal translocation was found to be low, and is suggested to be a factor in the low mortality of the fern and the subsequent resprouting seen after herbicide treatments (Hutchinson et al. 2010). Stocker et al. (2008) examined the effectiveness of herbicide alone or in combination with fire on the reduction of L. microphyllum in pine flatwoods and found 
that herbicide alone was effective in killing the above ground biomass, but resprouting from existing rhizomes occurred within two months. When herbicide was used in combination with prescribed fire treatments, herbicide use could be reduced by $50 \%$ with greater overall reduction of the infestation than with either treatment alone (Stocker et al. 2008).

Following herbicide or herbicide-fire treatments of $L$. microphyllum on three disturbed sites in southern Florida, Hutchinson and Langeland (2010) observed significant reduction in cover, but within two years, resprouting from rhizomes as well as new sporophytes (from germinated spores) were found, indicating the need for retreatment using these methods. While L. microphyllum was reduced, the returning plant cover varied and tended to shift to other nonnative species, rather than to native species (Hutchinson and Langeland 2010).

Combining methods may be the solution, but timing of the applications is critical. Hutchinson and Langeland (2006b, 2010) burned L. microphyllum infestations three months after applying herbicide. They noted that the ideal interval between treatments is still unclear, as is whether burning followed by herbicide or herbicide followed by burning is more effective in treating L. microphyllum. Although in this case a threemonth interval may be appropriate timing, Stocker et al. (2008) have generally recommended monitoring and retreating with herbicides at six-month intervals. Multiple treatments with one method, (i.e., herbicide) may be optimal at one interval, while a different interval may be more appropriate when the second treatment method differs from the first (i.e., herbicide followed by fire) and this should be considered when planning multiple treatments. 
Additionally, the life cycle of the fern must be considered. Lygodium microphyllum spores have a potential viability of four years (Stocker et al. 2008), and when shallowly buried in the soil, are protected from fire (Whelan 1995). Hutchinson and Langeland (2010) found that L. microphyllum spores are tolerant of most of the commonly used herbicides, including imazapyr, glyphosate, fluroxypyr, asulam, and triclopyr. The use of one of these herbicides followed by a burn may successfully reduce the standing L. microphyllum but will do nothing to the soil spore bank. As spores were found to be susceptible to metsulfuron (Hutchinson and Langeland 2010), one possible method could be prescribed burning followed by treatment with metsulfuron to kill the spores. However, metsulfuron may inhibit the recruitment of native ferns, and thus may not be appropriate in some plant communities (Hutchinson and Langeland 2011). Special care must be taken by herbicide ground applicators to minimize the further dispersal of spores via contamination of clothing and equipment, as this was found to be a significant contributor to reinfestation (Hutchinson and Langeland 2006a).

\section{Prescribed Fire}

Prescribed fire is inexpensive at $\$ 124-321$ per hectare $(\$ 50-130$ per acre) (Cleaves et al. 1999) and is effective for reducing above-ground biomass over large areas; however, some habitats are fire sensitive, and application requires trained personnel and may be limited to certain areas or times of year (Hutchinson et al. 2006). Because $L$. microphyllum resprouts from the rhizome, its eradication may require multiple burns, particularly hot burns or supplemental treatment by other means (DiTomaso et al. 2006).

In its native range, L. microphyllum resprouts from the rhizome after fire (Gooslby et al. 2003) and has been seen to do the same in the invaded range (Stocker et 
al. 2008). In contrast to herbicide-caused death, fire destroys the rachis mats, decreasing subsequent fire hazard, opening up the space for reestablishment of native plant cover, and potentially depositing nutrients in the soil. Fire was so successful initially at reducing one L. microphyllum infestation, that Stocker et al. (2008) expressed difficulty in detecting regrowth of L. microphyllum as a result of the abundant growth of other species. However, there is variation in the results of prescribed fire in the control of $L$. microphyllum, including some reports of increased L. microphyllum density post-burn (Hutchinson and Langeland 2006b), and in several sites where prescribed fire followed herbicide treatments, an influx of other nonnative species formed the new dominant cover (Hutchinson and Langeland 2010).

While prescribed fire has been used successfully to reduce infestation biomass in areas that are fire-adapted, it is unknown what effects fire has on spore viability. Two concerns are whether spores can be dispersed by fire-created updrafts, and whether such spores are viable and able to colonize new areas (Osborne et al. 2010, Stocker 2008).

Fire behavior is complex and depends on many factors, including the characteristics of the fuel (heterogeneity, vertical/horizontal distribution, continuity, flammability, depth, and bulk density), soil moisture, temperature, season, heat released, and duration (Bond and van Wilgen 1996, Whelan 1995). For example, in pine savannahs, fallen needles make up the fine fuels which, when suspended on grass tussocks, burn well $\left(500-800^{\circ} \mathrm{C}\right)$ because of their resins and ventilation (Slocum et al. 2003). Temperature measurements taken at the ground surface in longleaf pine forest by Glitzenstein et al. (1995) ranged from 274 to $452^{\circ} \mathrm{C}$. Depending on the characteristics of the substrate and the moisture content, temperatures below the soil surface, even just a 
few inches down, can be very different from those above (Whelan 1995). Moist soil will transfer heat, but rates vary in part according to soil surface temperatures. Trollope (1984 in Whelan 1995) suggests that with soil surface temperatures of less than $100^{\circ} \mathrm{C}$, soil moisture will conduct heat downward, but with soil surface temperatures of above $100^{\circ} \mathrm{C}$, some of the heat radiating down will evaporate soil water, retarding heat permeation. Typically, temperatures a few inches down will be significantly cooler than surface temperatures, regardless of moisture content (Whelan 1995). Given that L. microphyllum rachis mats can be similarly arranged (wiry, suspended over itself or other vegetation), it too may burn at relatively high temperatures, but its spores, if already embedded in the soil, may escape fatal heating.

The distribution of fuels will in part determine the type of fire; for instance, horizontally and vertically heterogeneous fuel (or moisture levels) will produce a patchy fire (Whelan 1995), which is often desirable to managers because unburnt portions provide refuge from the heat for native plant propagules and source populations for reestablishment. Unfortunately, invasive species' propagules may also find refuge there. If a sporulating fern happens to be growing in a patch spared by a fire, it may remain unaffected and thus a continuing source of viable spores. It is also possible that heat from the passing fire will radiate toward the patch and provide enough heat to damage the plant and kill the spores. Fires create convective flows of air, and mature spores may be caught in an updraft and dispersed to new sites; however, if exposure to temperatures common to fires kills spores, then subsequent dispersal may no longer be a concern (Floyd 1966). 


\section{RESEARCH OBJECTIVES}

Although burning kills plants, the effects of lower temperatures vary. Plant cells are damaged by heat indirectly or directly via several mechanisms, including protein denaturation (Whelan 1995). While protein denaturation typically occurs between 40 and $65^{\circ} \mathrm{C}$ (Hopkins and Hüner 2004), the rates of cell mortality vary in relation to duration of heat exposure and hydration of the cells (Bond and van Wilgen 1996, Whelan 1995). The cells of common mesophytes die between $50-55^{\circ} \mathrm{C}$ (Hare 1961), but dehydrated organs can tolerate higher temperatures (Bond and van Wilgen 1996).

As dormant L. microphyllum spores are relatively dehydrated, the objectives of this study were to determine experimentally the effects of temperature and duration of heat exposure on spore germination and to define the lowest combination of temperature and duration of exposure that would completely reduce spore viability. I hypothesized that spore viability would decrease with increasing temperatures and durations of exposure.

\section{MATERIALS AND METHODS}

All experiments used sporulating L. microphyllum fronds collected (detailed below) from either Everglades National Park, Florida, or South Florida Water Management District N-17. Fronds were transported to Florida International University (FIU) using Florida Department of Agriculture and Consumer Services permit no. 2013022 , and placed in a plant press in the laboratory to dry and release spores. One or $10 \mathrm{mg}$ spore samples were weighed on a Mettler AE240 analytical balance (accuracy $=0.01 \mathrm{mg}$ ) (Mettler Toledo, LLC, Columbus, OH), placed in tin cups (Costech Analytical 
Technologies, Inc., Valencia, CA) and stored in glass scintillation vials at room temperature.

\section{Experimental conditions}

A series of preliminary experiments were performed to establish growth conditions, heating methods, appropriate experimental protocols and temperature ranges and durations. These experiments will be referred to as Preliminary Experiments, while the final experiments will be referred to as Final Experiments 1 and 2. Except where noted otherwise, the following methods were followed for all spore germination experiments.

The general experimental approach was to give spores heat treatments for different times and temperatures, always having an unheated control, then to plate the spores out on nutrient agar, let them grow in a temperature and light controlled growth chamber, then count the number of germinated and ungerminated spores. The same day that heat treatments were applied, treated and control spores were suspended in distilled water, then plated onto $20 \mathrm{~cm}$ petri dishes with $0.8 \%$ agar medium containing ParkerThompson basal nutrients (PhytoTechnology Laboratories, Shawnee Mission, KS). Plated spores were grown in a growth chamber (Environmental Growth Chambers model GC8-2H, Chagrin Falls, OH) under a 13/11 light/dark cycle with temperatures set to $26 / 24^{\circ} \mathrm{C}$. Temperature loggers were placed in the chamber to monitor temperature fluctuations. After two weeks, percent germination was determined by dividing petri dishes into four equal quadrants and using a dissecting microscope to scan each quadrant for spores. In the early experiments, the first 25 spores encountered in a quadrant scan were scored as germinated or ungerminated. In the Final Experiments, 50 spores per 
quadrant were scored as before. The total number of spores germinated was determined from the sum of the quadrants.

\section{Preliminary Experiments}

\section{$80^{\circ} \mathrm{C}, 1-7$ days:}

It is not uncommon for certain elements (pine cones, logs) in a burned area to smolder for hours or days after the flames have passed (Beadle 1940, Whelan 1995). To determine whether extended heating had any effect on spore viability, I tested the effects of spore exposure to $80^{\circ} \mathrm{C}\left(176^{\circ} \mathrm{F}\right)$ for $0,1,3,5$ and 7 days. Spores for this experiment were collected from ENP in 2012 and were 13 months old at the time of the experiment. I used a drying oven with stable heat settings and added spore samples $(\mathrm{n}=3,0.01 \mathrm{~g}$ in glass scintillation vials) starting with the 7-day treatments, and adding a group every second day until all the samples were in the oven; samples were removed simultaneously for plating. Controls ( 0 days, $n=3$ ) were spores from the same batch but unheated and plated at the same time. This experiment was also used to determine the time required for germination to obtain accurate counts. All plated samples were assayed weekly for 4 weeks, and percent germination recorded for later comparison. This experiment was conducted in September 2013.

\section{$35-80^{\circ} \mathrm{C}, 0.25-12$ hours:}

To explore more realistic durations of exposure and lower temperatures, I exposed spores to $35^{\circ} \mathrm{C}\left(95^{\circ} \mathrm{F}\right), 50^{\circ} \mathrm{C}\left(122^{\circ} \mathrm{F}\right), 65^{\circ} \mathrm{C}\left(149^{\circ} \mathrm{F}\right), 80^{\circ} \mathrm{C}\left(176^{\circ} \mathrm{F}\right)$, and shorter exposure durations: $0.25,0.5,1,3,6$, and 12 hours. Spores used for the experiment were from the same 2012 ENP collection and were 17 months old at the beginning of the experiment. Each temperature group was treated separately, resulting in spaced treatments. The group 
receiving $35^{\circ} \mathrm{C}(\mathrm{Jan} 31)$ was followed by the $50^{\circ} \mathrm{C}$ group $(\mathrm{Feb} 4)$, then the $65^{\circ} \mathrm{C}$ group (Mar 20), and finally the $80^{\circ} \mathrm{C}$ group (April 23), making the last group actually 19 months old. Each treatment had three replicates. Samples of spores were stored and heated in glass scintillation vials. One $\mathrm{mL}$ distilled water was added to each vial to suspend the spores, allow imbibition for 20 minutes, and to achieve better dispersal across the agar. Percent germination was calculated at 2 weeks, after which gametophytes began to obscure the view of ungerminated spores. Controls were unheated samples from the same group and plated on the same day as the treatments beginning with $50^{\circ} \mathrm{C}$ (no control for $35^{\circ} \mathrm{C}$ ). Each control had two replicates. This experiment was conducted January to April 2014.

\section{$35-65^{\circ} \mathrm{C}, 5-25$ minutes:}

Prompted by responses to shorter durations of exposure and to spore age, I again tested these lower temperatures with fresh spores collected from SFWMD N-17 canal in Dec 2013. Spores were 6 months of age when the experiment was done. I applied temperatures of $35^{\circ} \mathrm{C}\left(95^{\circ} \mathrm{F}\right), 50^{\circ} \mathrm{C}\left(122^{\circ} \mathrm{F}\right), 65^{\circ} \mathrm{C}\left(149^{\circ} \mathrm{F}\right)$ for durations of each 5,15 , and 25 minutes. In this experiment, I used thin tin cups instead of glass scintillation vials to heat the spores over concerns that the vials created insulating microenvironments. The tin cups were opened, added to $1 \mathrm{~mL}$ distilled water in glass vials, and shaken to suspend the spores, which were then allowed to presoak for 20 minutes and then plated. For each treatment and controls there were five replicates. This experiment was conducted in May 2014. 
$+80^{\circ} \mathrm{C}, 5-60$ minutes:

Using the same (SFWMD N-17 Dec 2013) group of spores, I exposed spores to the same three temperatures $\left(35,50,65^{\circ} \mathrm{C}\right)$ for one hour, and also exposed spores to $80^{\circ} \mathrm{C}$ for $5,15,25$, and 60 minutes, again using tin cups instead of scintillation vials $(n=5)$. After the 20-minute presoak, suspended spores were plated on agar as in previous experiments. At the time of the heat treatments the spores were 7 months of age. Controls were from the same batch and had five replicates. The experiment was conducted in July 2014.

\section{Spore soak times:}

A range of preliminary soak times from $45 \mathrm{~min}$. to more than 40 hours have been reported for experiments with spore germination (Ballesteros and Walters 2007, Hevly 1963, Philippi and Richards 2007, Ranal 1999, Towill 1978). The effects of differing soak times on L. microphyllum spore viability are unknown, although they may be significant, as young L. microphyllum sporophytes are susceptible to drowning (Philippi and Richards 2007). To see the effects of pre-soaking on germination, spores were subjected to soak times of zero (dry-sown spores), 10 minutes, 1 hour, and 40 hours. Spores for this experiment were collected in August, 2014 from ENP and were three months old at the time of the experiment. Subsequent experiments used the pre-soaking time determined by this experiment, so as to reduce any negative effects of suboptimal soak time. This experiment was conducted in November 2014.

\section{Final Experiment 1: Spore germination at $\leq 95^{\circ} \mathrm{C}$ :}

In this experiment I exposed spores to temperatures of up to $95^{\circ} \mathrm{C}$ for durations from 5 to 60 minutes. Results from preliminary experiments indicated that these 
durations are relevant to viability at various temperatures within the protein denaturation range. Although L. microphyllum spores have been said to possess 4 years of viability (Lott in Hutchinson et al. 2006), spore age was found in my previous experiments to decline to $2 \%$ after only 2 years. In these final experiments, a single batch of spores was used; they were collected from ENP August, 2014 and were four months old at the time of the first experiment. Each treatment had three replicates. Spore samples were heated in tin cups in a muffle furnace (Fisher Scientific Isotemp model 550-12, Hampton, NH). Experimental treatments were $50^{\circ} \mathrm{C}\left(122^{\circ} \mathrm{F}\right), 65^{\circ} \mathrm{C}\left(149^{\circ} \mathrm{F}\right), 80^{\circ} \mathrm{C}\left(176^{\circ} \mathrm{F}\right)$, or $95^{\circ} \mathrm{C}$ $\left(203^{\circ} \mathrm{F}\right)$ for durations of $5,15,30$ or 60 minutes, each with three replicates. Three temperature-logging iButton sensors (Maxim Integrated, San Jose, CA) were used to track internal oven temperatures for all but the $95^{\circ} \mathrm{C}$ treatment, which is out of the range of detection for the iButtons used in the experiment. The iButtons were placed with samples in the furnace for each run. The temperatures were logged every minute and time-stamped so that they could be accurately matched to the treatments. Readings from the iButtons were averaged to obtain the mean, standard error and range of true temperatures in the furnace (Table 1). Controls $(n=4)$ were spores that had been identically stored but that were not heated. After heating, tin cups were opened into scintillation vials with $1 \mathrm{~mL}$ distilled water, and left to presoak for 10 minutes before plating. Treatments that had zero germination at two weeks (spores exposed to $95^{\circ} \mathrm{C}$ for all durations, and all the treatments of $100^{\circ} \mathrm{C}$ and above) were resealed and allowed to continue development for an additional week in the growth chamber and assayed again. These secondary counts were more exhaustive than the initial counts, and in each quadrant at least 100 spores were counted and scored accordingly. Of these, the spore 
samples exposed to $95^{\circ} \mathrm{C}$ for 60 minutes were assayed a third time at five weeks with counts exceeding 800 spores per plate. The experiment was begun in December 2014. Final Experiment 2: Spore germination at $\geq 100^{\circ} \mathrm{C}$ :

The second final experiment used the same batch of spores as the first Final Experiment (now seven months of age), temperatures of at least $100^{\circ} \mathrm{C}$ and short durations of less than one minute, as could be expected given a passing fire. Treatments included $100^{\circ} \mathrm{C}\left(212^{\circ} \mathrm{F}\right)$ and $300^{\circ} \mathrm{C}\left(572^{\circ} \mathrm{F}\right)$ for 5 or 30 seconds with five replicates. Spore samples, contained in tin cups, were heated by placing them into a hotplatepreheated glass scintillation vial with a TJ36 Series type K thermocouple (Omega, Westlake Village, CA). The thermocouple was connected to a CR23X Micrologger (Campbell Scientific, Inc., North Logan, UT) to verify temperatures of exposures every second. Samples were removed from the vials quickly to halt residual continued heating. Tin cups were opened in the vials, $1 \mathrm{~mL}$ distilled water added and allowed 10 minutes to presoak before plating. Controls $(n=5)$ were from the same stored batch of spores but unheated. This experiment was conducted in March 2015.

\section{Statistical Analysis:}

Only the final experiments were analyzed statistically. To analyze the overall trend of combined durations within each temperature group, I used a generalized linear model assuming a binomial distribution of the dependent variable and logit link. I initially compared each temperature/duration combination to the control using the generalized linear model. I then compared durations within each temperature using Tukey tests from the multcomp package in R (Hothorn et al. 2008). 


\section{RESULTS}

\section{Preliminary Experiments}

\section{$80^{\circ} \mathrm{C}, 1-7$ days:}

Germination of untreated controls averaged 30\% between two and three weeks, and reached $45 \%$ by the end of four weeks. However, because of the large size of the germinated spores (gametophytes), counts taken in the last week were likely biased from reduced visibility of ungerminated spores around and underneath the gametophytes. At the time of the experiment, the spores used were approximately one year in age. None of the spores exposed to $80^{\circ} \mathrm{C}$ for one or more days surpassed rates of $5 \%$ germination. This indicates that there is likely a significant effect of $80^{\circ} \mathrm{C}$ for one or more days on spore viability.

\section{$35-80^{\circ} \mathrm{C}, 0.25-12$ hours:}

While there was a noticeable reduction in germination over increasing time as well as increasing temperature, some of this effect may be attributed to the inadvertent introduction of spore age as a variable, as the four temperatures were applied successively over an 11 week period. When all treatments were standardized to their respective controls, there was still an obvious reduction in spore viability at the higher temperatures $\left(65\right.$ and $80^{\circ} \mathrm{C}$ ) after one hour, but not much reduction, if any, for the lower temperatures ( 35 and $50^{\circ} \mathrm{C}$ ) even after 12 hours of exposure. Germination of controls was $15 \%$ to $3 \%$.

\section{$35-65^{\circ} \mathrm{C}, 5-25$ minutes:}

With this group, which used younger spores than the previous experiments, germination of controls exceeded $40 \%$. The low temperatures of $35^{\circ} \mathrm{C}, 50^{\circ} \mathrm{C}$ and $65^{\circ} \mathrm{C}$ had little effect, with the greatest reduction in germination still yielding 33\% germination 
even after 25 minutes. For comparison only, I concurrently germinated spores from the first group (now approximately 2 years in age) and saw only $2 \%$ germination, which suggested that spore age can greatly affect results.

$+80^{\circ} \mathrm{C}, 5-60$ minutes:

By this experiment, the spores were 7 months old, and the control again showed reduced germination compared to the previous control, reaching only $24 \%$ germination. Exposure to $35^{\circ} \mathrm{C}$ for an hour did not have any effect, while $50^{\circ} \mathrm{C}$ resulted in germination rates of about $17 \%$. However, $65^{\circ} \mathrm{C}$ for one hour and $80^{\circ} \mathrm{C}$ for 5 minutes both reduced germination to below $10 \%$. At least 25 minutes at $80^{\circ} \mathrm{C}$ resulted in germination rates of $3 \%$. After standardizing the groups to their respective controls, $80^{\circ} \mathrm{C}$ showed the greatest effect. At one hour, $65^{\circ} \mathrm{C}$ appeared to have a significant effect as well, but those spores exposed to $35^{\circ} \mathrm{C}$ for one hour also showed some reduced germination, so there may have been other variables at play.

\section{Spore soak times:}

Samples were too small for statistical analysis, but differences were not large among the soak times. All treatments yielded germination rates of $40 \%$ or higher, with the maximum rate of nearly $66 \%$ occurring for the short soak of 10 minutes. Dry-sown yielded an intermediate rate of 53\% while 1 hour- and 40 hour-soaked both yielded $45 \%$. All subsequent experiments used 10 minute soak periods.

Final Experiment 1: Spore germination at $\leq 95^{\circ} \mathrm{C}$ :

Temperature inside the muffle furnace varied from 1 to $8^{\circ} \mathrm{C}$ from the set points and average temperatures in the oven were 0.6 to $4.8^{\circ} \mathrm{C}$ greater than the target temperatures (Table 1). 
When all durations were considered together, L. microphyllum spore germination decreased with increasing temperatures (Fig. 1). No spores had germinated after two weeks at $95^{\circ} \mathrm{C}$ for any of the durations, so this treatment was removed from further analysis. Each temperature/duration combination differed significantly from the control (p $<0.0001$ ) except for $50^{\circ} \mathrm{C}$ at 5 min. (Fig. 2). Germination of controls was $31 \%$.

Within a temperature group, differences in germination between durations varied among temperatures. Spores exposed to $50^{\circ} \mathrm{C}$ for 5 minutes showed no difference in viability compared to controls. All longer durations at $50^{\circ} \mathrm{C}$ differed significantly from the $5 \mathrm{~min}$. treatment but did not differ among themselves. All of the durations at $65^{\circ} \mathrm{C}$ differed significantly from the controls, but did not differ among themselves. All of the durations at $80^{\circ} \mathrm{C}$ differed significantly from the controls and differed among themselves. The 15 min. duration had significantly less germination than the 5 or 30 min. durations, but did not differ from the $60 \mathrm{~min}$. duration. The 5 and $15 \mathrm{~min}$. durations did not differ from each other but had significantly greater germination than the 60 min. duration.

Although when counted at two weeks, all spores treated to 5 or more minutes of $95^{\circ} \mathrm{C}$ remained ungerminated and were presumed dead, low levels of germination occurred over time in these plates. At 3 weeks, mean germination counts per 800 spores (and percent germination) were $4.33(0.5 \%)$ at $5 \mathrm{~min} . ; 10(1.25 \%)$ at $15 \mathrm{~min} . ; 0.667$ $(0.08 \%)$ at $30 \mathrm{~min} ; 0(0 \%)$ at $60 \mathrm{~min}$. Only the $60 \mathrm{~min}$. group was assayed again at 5 weeks; some germination occurred and reached $10(1.3 \%)$. These gametophytes were stunted but green and potentially able to produce sporophytes. 


\begin{tabular}{|c|c|c|c|c|c|}
\hline Target $\left({ }^{\circ} \mathrm{C}\right)$ & Dur. $(\mathrm{min})$ & Temp $\left({ }^{\circ} \mathrm{C}\right)$ & SE & Range $\left({ }^{\circ} \mathrm{C}\right)$ & Diff. $\left({ }^{\circ} \mathrm{C}\right)$ \\
\hline 50 & 5 & 54.81 & 0.11 & 55 & 4.81 \\
\hline 50 & 15 & 54.11 & 0.22 & $52-55$ & 4.11 \\
\hline 50 & 30 & 52.39 & 0.04 & $52-53$ & 2.39 \\
\hline 50 & 60 & 51.54 & 0.23 & $42-53$ & 1.54 \\
\hline 65 & 5 & 67.64 & 0.03 & 68 & 2.64 \\
\hline 65 & 15 & 67.50 & 0.21 & $66-68$ & 2.50 \\
\hline 65 & 30 & 66.13 & 0.04 & 66 & 1.13 \\
\hline 65 & 60 & 67.29 & 0.16 & $66-71$ & 2.29 \\
\hline 80 & 5 & 81.78 & 0.46 & $81-83$ & 1.78 \\
\hline 80 & 15 & 81.69 & 0.14 & $81-82$ & 1.69 \\
\hline 80 & 30 & 81.46 & 0.09 & $80-82$ & 1.46 \\
\hline 80 & 60 & 80.64 & 0.03 & $80-81$ & 0.64 \\
\hline
\end{tabular}

Table 1. Target temperatures and durations (Dur), measured temperatures of treatments (Mean, SE, Range), and difference (Diff.) between target and mean measured temperatures for experiment 1 treatments. No data for $95^{\circ} \mathrm{C}$. 


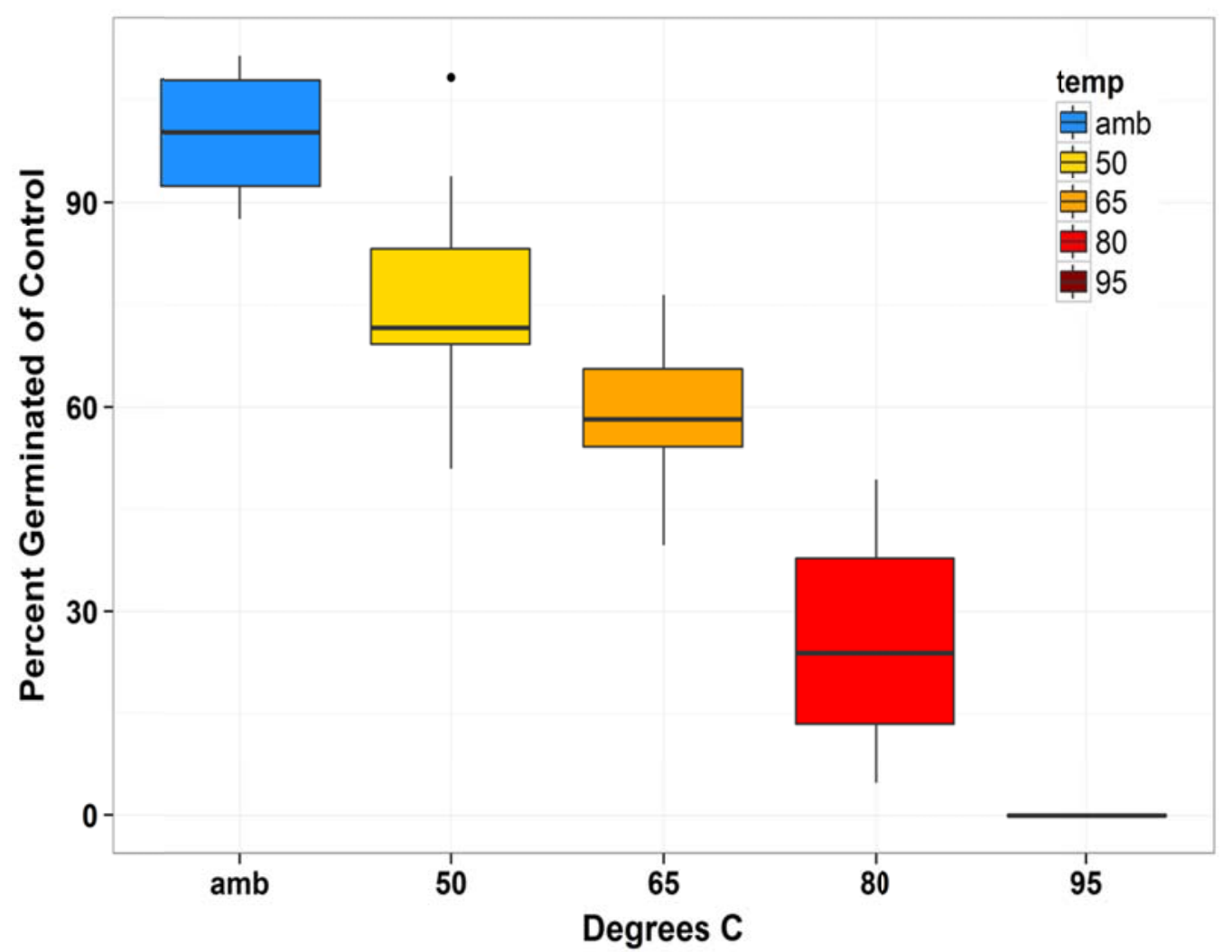

Figure 1. L. microphyllum spore germination expressed as percent of germination of controls for each temperature treatment; heat duration of 5 to $60 \mathrm{~min}$. combined at each temperature. $\mathrm{amb}=$ ambient temperature for controls. 


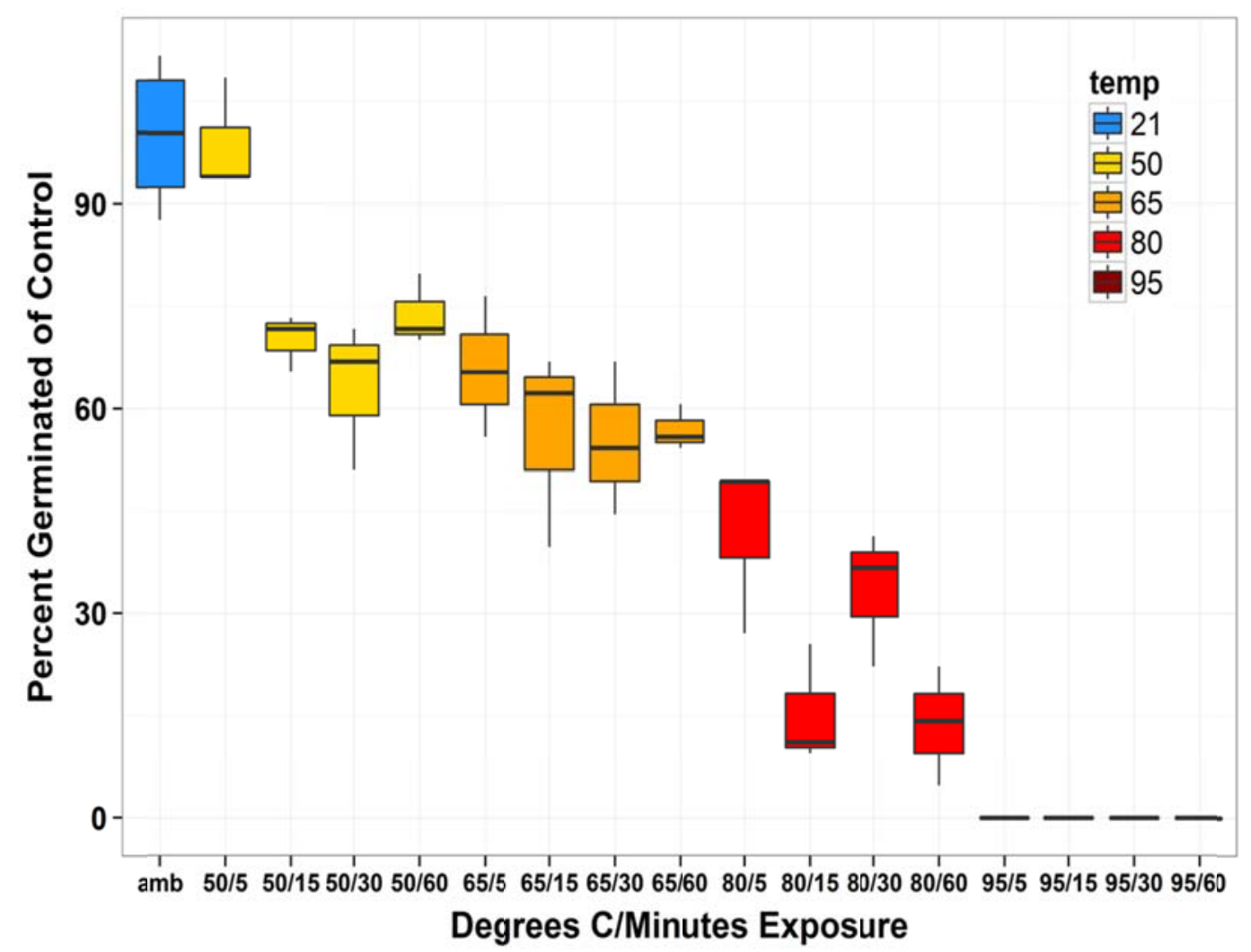

Figure 2. L. microphyllum spore germination expressed as percent of germination of controls for each temperature and heat duration treatment. $21 / \mathrm{amb}=$ ambient temperature for controls. 


\section{Final Experiment 2: Spore germination at $\geq 100^{\circ} \mathrm{C}$ :}

Similarly, in experiment 2, where temperature varied across the bottom of the glass vial above the hotplate, temperatures varied from 0.6 to $3.5^{\circ} \mathrm{C}$ (with one exception of $99^{\circ} \mathrm{C}$ below the $300^{\circ} \mathrm{C}$ target) from the target temperatures. The mean logged temperatures during the $100^{\circ} \mathrm{C} 5$ and 30 second targets were $103.1^{\circ} \mathrm{C}$ and $102.5^{\circ} \mathrm{C}$, respectively. The $300^{\circ} \mathrm{C}$ target actually averaged $286^{\circ} \mathrm{C}$ because of the single replicate with a $99^{\circ} \mathrm{C}$ deviation in temperature; excluding this sample, the mean logged temperature was $295.3^{\circ} \mathrm{C}$.

After five seconds at $100^{\circ} \mathrm{C}$ and 2 weeks in the growth chamber, not a single spore germinated (Fig. 3). No germination resulted after 30 seconds of $100^{\circ} \mathrm{C}$, and spores subjected to near $300^{\circ} \mathrm{C}$ for 5 seconds were brown, appearing charred (Fig. 4). No germination was seen in any scan of 400-800 spores per plate. These samples were also resealed and allowed another 10 days in the growth chamber. When re-assayed, average germination reached only $0.23 \%$ for spores exposed to 5 seconds of $100^{\circ} \mathrm{C}$; the other treatments remained at zero germination. Germination of controls was $21 \%$. 


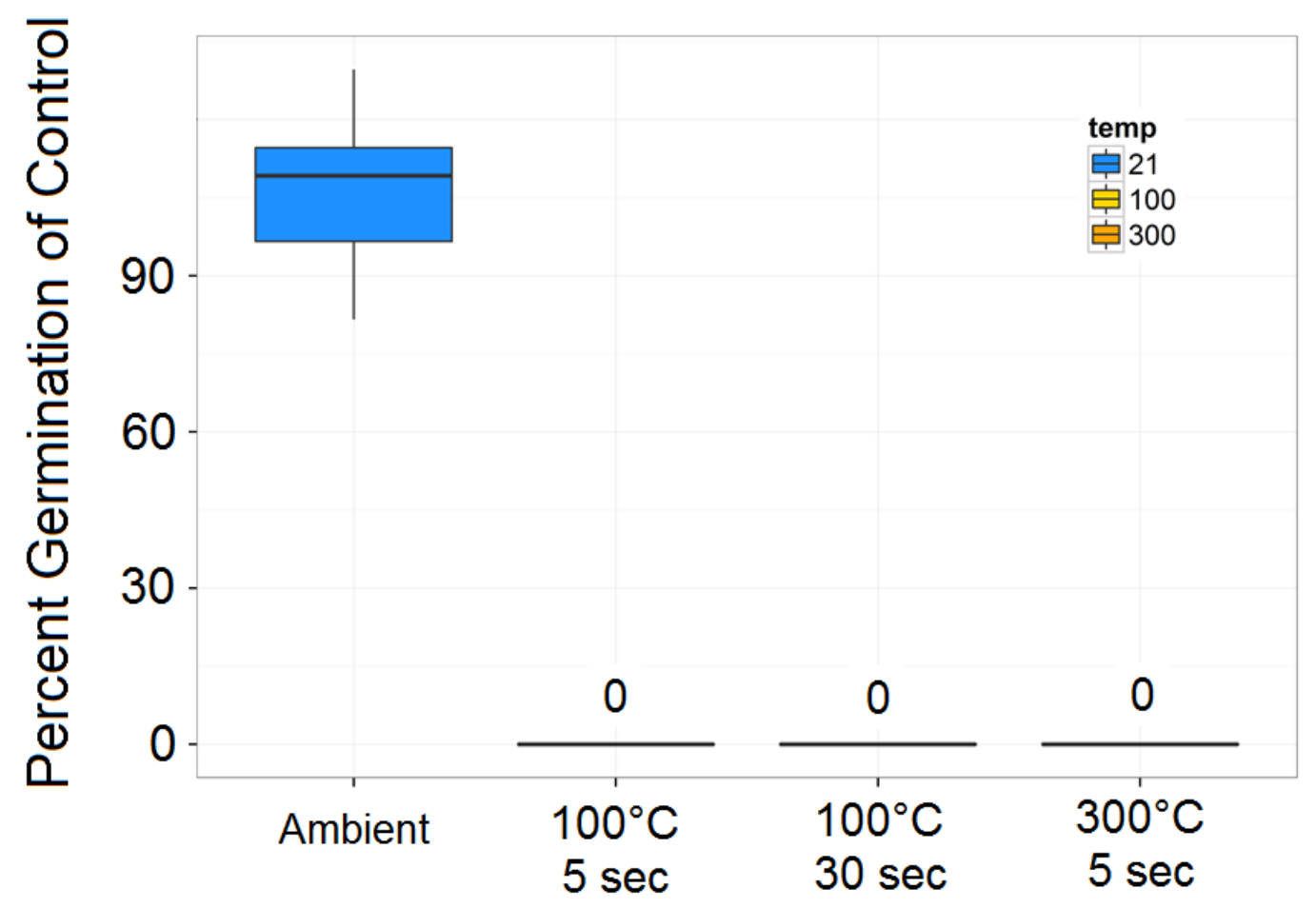

Figure 3. L. microphyllum spore germination expressed as percent of germination of controls for each temperature/heat duration treatment for temperatures $\geq 100^{\circ} \mathrm{C}$. Ambient $=$ ambient temperature for controls.
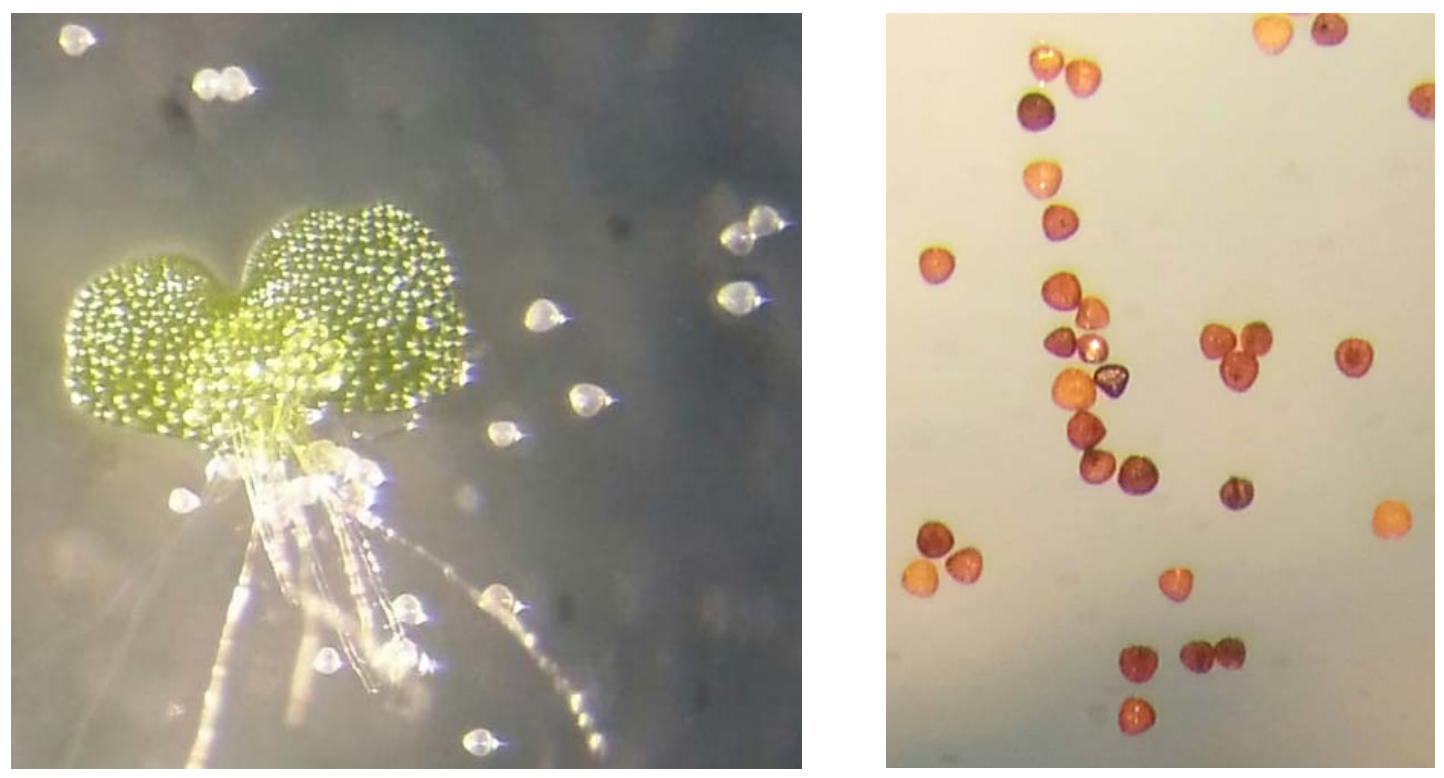

Figure 4. Viable L. microphyllum spores (left) and nonviable spores after exposure to $300^{\circ} \mathrm{C}$ for 5 seconds (right). 


\section{DISCUSSION}

Because prescribed fire is used to manage infestations of the invasive fern Lygodium microphyllum, this study addresses the unknown effects of fire on spore viability. Of the many characteristics of fire that may affect spore viability, I selected temperature and duration of exposure.

Through this research I determined the lower bound of temperatures and durations required to significantly reduce spore viability. Generally, increases in temperature reduced spore viability, as did increases in duration of exposure; and these factors were inversely related. A relatively cool temperature of $50^{\circ} \mathrm{C}$, when applied for durations of at least 15 minutes significantly reduced spore viability as compared to controls. Temperatures of at least $100^{\circ} \mathrm{C}$ for only 5 seconds resulted in over $99 \%$ loss of viability; however, 30 seconds of exposure at the same temperature resulted in $100 \%$ reduction of viability. Despite relative desiccation and thus tolerance of higher temperatures than vegetative tissue, L. microphyllum spores are vulnerable to relatively low temperatures, considering the range of temperatures potentially experienced in a fire. Although fire is highly variable in the field, temperatures often reach $700^{\circ} \mathrm{C}$ or more in native Florida habitats (Wally et al. 2006, Whelan 1995). Since 30 seconds of exposure to temperatures of $100^{\circ} \mathrm{C}$ in my study yielded $100 \%$ spore death, any spores exposed to this treatment and then dispersed will not be able to colonize new areas. Osborne et al. (2010) found similarly encouraging results when looking at uninvaded sawgrass (Cladium jamaicense) plots neighboring burned L. microphyllum-infested plots. They found only one of ten of the uninfested plots became colonized after the prescribed burn, and all the infested sites had greatly reduced L. microphyllum biomass in this marsh. For infested areas that are 
fire-adapted, with temperatures near sporulating fronds of at least $100^{\circ} \mathrm{C}$, prescribed fire is a beneficial control method both for plants that get burned and for spores of nearby unburned plants.

When determining temperature limits for spore viability, there were challenges in executing the desired treatments. While the muffle furnace was useful for providing temperatures over a wide range, when the internal sensor recorded a dip in temperature, as from a brief opening of the door, the oven's heating mechanism produced a temperature spike and slow cooling back to the set point which changed the average temperatures of exposures. Additionally, humidity in the furnace could not be controlled and may have been a factor in spore death that warrants additional study. Though the hotplate used in the second final experiment maintained relatively constant temperatures, it was difficult to remove the glass vials quickly from the stand. Holding the tin cups by tweezers over the hot plate was considered, but verifying temperatures of exposure would have been very difficult in this scenario.

Spores used in the Final Experiments were collected from a single population in Everglades National Park. As there may be differences among populations, it would be useful to compare baseline spore viability and heat tolerance of spores among several populations across Florida. Lygodium microphyllum spores were reported by Michael Lott (in Hutchinson et al. 2006) to maintain their viability for four years. Hutchinson (2010) found $1.5 \%$ germination of spores that were 7.25 years old after storage under dry conditions. In contrast to these claims, I saw a marked decrease in germination of labstored spores after only 2 years, with germination rates scarcely reaching $2 \%$. While my spores were kept in a cool, dark environment, I could not control for humidity, and this 
may be an important factor regarding longer term viability. Relative humidity may also affect spore viability in response to burning, and should be likewise investigated, considering Florida's typically humid climate. These data would inform monitoring and retreatment protocols.

It may be helpful to explore the degree of allelopathy in the invaded range, as well as whether there is any interaction with prescribed burning, such as resultant residual allelopathic chemicals affecting the reestablishment of native plant species. The Wang et al. (2014) study on L. microphyllum leachates inhibiting the growth of herbaceous plants may indicate an additional strategy of invasion. However, it is possible that some native plants in the invaded range may have allelopathic effects strong enough to overcome those of L. microphyllum. Call et al. (2007) obtained low germination rates of $L$. microphyllum spores on a substrate of Myrica cerifera leaves in one of their experiments and suggested allelopathic effects as the cause. The possibility of native plant allelopathy as an additional control strategy warrants further study, particularly in combined treatments; for example, prescribed fire could be used first to reduce standing biomass followed by application of $M$. cerifera extract, tea, or leaves to inhibit spore germination. Results from my experiments indicate that viability of unburnt spores depends on temperature and duration of heat exposure. Relatively low temperatures kill spores, significantly reducing spore viability and thus alleviating concerns over their subsequent dispersal by fire-created updrafts. Considering that exposure to $100^{\circ} \mathrm{C}$ for 30 seconds kills $100 \%$ of spores, prescribed fire could be the ideal treatment method for fire-tolerant habitats infested with L. microphyllum. Applicability of these results could be improved through the development of heat maps of actual prescribed burns of L. microphyllum that 
show the spatial distribution of on-site temperatures and their durations in combination with post-burn regrowth (both resprouting and spore germination) data. Heat maps would inform management efforts to ensure the exposure of sporulating fronds to fatal temperatures and durations. This knowledge will allow us to more accurately predict fire's effects on the spread of this invasive exotic. 


\section{REFERENCES}

Ballesteros, D., and Walters, C. 2007. Water properties in fern spores: sorption characteristics relating to water affinity, glassy states, and storage stability. Journal of Experimental Botany 58:1185-1196.

Beckner, J. 1968. Lygodium microphyllum, another fern escaped in Florida. American Fern Journal 58(2):93-94.

Beadle, N.C.W. 1940. Soil temperatures during forest fires and their effect on the survival of vegetation. Journal of Ecology 28(1):180-192.

Bond, W.J., and van Wilgen, B.W. 1996. Fire and Plants. Chapman \& Hall, London, U.K.

Call, E.M., Brandt, L.A., and Deangelis, D.L. 2007. Old World Climbing Fern (Lygodium microphyllum) spore germination in natural substrates. Florida Scientist 70(1):55-61.

Christenhusz, M.J.M., and Chase, M.W. 2014. Trends and concepts in fern classification. Annals of Botany 113:571-594.

Clark, D.W. 2002. The effect of old world climbing fern (Lygodium microphyllum (Cav.) R. Brown) on south Florida cypress (Taxodium distichum (L.) Rich.) swamp plant and insect community structure. MS Thesis. University of Florida. 86pp.

Cleaves, D.A., Haines, T.K., and Martinez, J. 1999. Prescribed burning costs: Trends and influences in the National Forest System. USDA Forest Service Technical Report PSW-GTR-173:277-287.

Darby, C., and McKercher, L.R. 2002. Bones wrapped in Lygodium microphyllum rachis suggest a potential problem for wildlife. Wildland Weeds 5(4):14.

de Groot, R.S., Wilson, M.A., and Boumans, R.M.J. 2002. A typology for the classification, description and valuation of ecosystem functions, goods and services. Ecological Economics 41:393-408.

de Groot, G.A., Verduyn, B., Wubs, E.R.J., Erken, R.H.J., and During, H.J. 2012. Interand intraspecific variation in fern mating systems after long-distance colonization: the importance of selfing. BMC Plant Biology 12(3):1-12.

DiTomaso, J.M., Brooks, M.L., Allen, E.B., and Minnish, R. 2006. The Use of Fire as a Tool for Controlling Invasive Plants. California Invasive Plant Council.

Ferriter, A. 2001. Lygodium Management Plan for Florida. Florida Exotic Pest Plant Council Lygodium Task Force Report. 51pp.

Ferriter, A., and Pernas, T. 2006. An explosion in slow motion: tracking the spread of Lygodium microphyllum in Florida. Wildland Weeds 9:7-9. 
Floyd, A.G. 1966. In Whelan, R.J. 1995. The Ecology of Fire. Cambridge University Press: U.K.

Gandiaga, S., Volin, J.C., Kruger, E.L., and Kitajima, K. 2009. Effects of hydrology on the growth and physiology of an invasive exotic, Lygodium microphyllum (Old World climbing fern). Weed Research 49:283-290.

Gandolfo, M.A., Nixon, K.C., Crepet, W.L., and Ratcliffe, G.E. 2000. Sorophores of Lygodium Sw. (Schizaeaceae) from the Late Cretaceous of New Jersey. Plant Systematics and Evolution 221:113-123.

Glitzenstein, J.S., Platt, W.J., and Streng D.R. 1995. Effects of fire regime and habitat on tree dynamics in North Florida longleaf pine savannas. Ecological Monographs 65(4):441-476.

Goolsby, J.A., Wright, A.D., and Pemberton, R.W. 2003. Exploratory surveys in Australia and Asia for natural enemies of Old World climbing fern, Lygodium microphyllum: Lygodiaceae. Biological Control 28:33-46.

Goolsby, J.A., de Barro, P.J., Makinson, J.R., Pemberton, R.W., Hartley, D.M., Frohlich, D.R. 2006. Matching the origin of an invasive weed for selection of a herbivore halotype for a biological control programme. Molecular Ecology 15:287-297.

Hare, R.C. 1961. Heat effects on living plants. U.S. Department of Agriculture, Forest Service, Southern Forest Experiment Station. New Orleans, LA: Occasional Paper $183.32 \mathrm{pp}$.

Hevly, R.H. 1963. Adaptations of Cheilanthoid ferns to desert environments. Journal of the Arizona Academy of Science 2: 164-174.

Hopkins, W.G., and Hüner, N.P.A. 2004. Introduction to Plant Physiology, 3rd ed. John Wiley \& Sons, Inc., USA.

Hothorn, T., Bretz, F., and Westfall, P. 2008. Simultaneous inference in general parametric models. Biometrical Journal 50(3):346-363.

Hutchinson, J.T. 2006. Additional report of Lygodium microphyllum mats as a potential problem for wildlife. IN Barrett, M.A., L.A. Brandt, and B. Thomas Jr. 2006. Monitoring Ground Treatments of Old World Climbing Fern (Lygodium microphyllum) on the Arthur R. Marshall Loxahatchee National Wildlife Refuge: A Follow-up Report. Wildland Weeds, Winter:4-7.

Hutchinson, J.T. 2010. Physiological characteristics of herbicides and management of Old World Climbing Fern (Lygodium microphyllum). Ph.D. dissertation. Gainesville, FL: The University of Florida. 157 p.

Hutchinson, J.T., and Langeland, K.A. 2006a. Potential spread of Lygodium microphyllum spores by herbicide applicators. Wildland Weeds, Spring:13-15. 
Hutchinson, J.T., and Langeland, K.A. 2006b. Survey of control measures on Old World Climbing Fern (Lygodium microphyllum) in southern Florida. Florida Scientist 69(4): 217-223.

Hutchinson, J.T., and Langeland, K.A. 2010. Monitoring of applied management techniques to control Old World Climbing Fern (Lygodium microphyllum) in disturbed habitat. Florida Scientist 73(3):262-273.

Hutchinson, J.T., and Langeland, K.A. 2011. Tolerance of Old World Climbing Fern (Lygodium microphyllum) Spores to Herbicides. Invasive Plant Science and Management 4(4):411-418.

Hutchinson, J.T., and Langeland, K.A. 2014. Tolerance of Lygodium microphyllum and L. japonicum spores and gametophytes to freezing temperature. Invasive Plant Science and Management 7:328-355.

Hutchinson, J., Ferriter, A., Serebesoff-King, K., Langeland, K., and Rodgers, L. (eds.) 2006. Old World Climbing Fern (Lygodium microphyllum) Management Plan for Florida. Florida Exotic Pest Plant Council Lygodium Task Force Report, $2^{\text {nd }}$ Ed. Available online at http://www.fleppc.org/Manage_Plans/Lygo_micro_plan.pdf. Accessed 17 October 2013.

Hutchinson, J.T., Langeland, K.A., MacDonald, G.E., and Querns, R. 2010. Absorption and translocation of glyphosate, metsulfuron, and triclopyr in Old World Climbing Fern (Lygodium microphyllum). Weed Science 58:118-125.

Jose, S., Singh, H.P., Batish, D.R., and Kohli, R.K. 2013. Invasive Plant Ecology. Taylor \& Francis Group, Boca Raton, FL.

Lake, E.C., Smith, M.C., Pratt, P.D., Boughton, A.J., and Pemberton, R.W. 2014. Dispersal and establishment of new populations of the biological control agent Floracarus perrepae (Acariformes: Eriophyidae) on Old Wolrd Climbing Fern Lygodium microphyllum (Polypodiales: Lygodiaceae). Florida Entomologist 97(2):827-829.

Lott, M. S., Volin, J.C., Pemberton, R.W., Austin, D.F. 2003. The reproductive biology of the invasive ferns Lygodium microphyllum and L. japonicum (Schizaeaceae): Implications for invasive potential. American Journal of Botany 90(8):1144-1152.

Lynch, R.L., Chen, H., Brandt, L.A., Mazzotti, F.J. 2009. Old World Climbing Fern ( invasion in hurricane caused treefalls. Natural Areas Journal 29(3):210-215.

Madeira, P.T., Pemberton, R.W., and Center, T.D. 2008. A molecular phylogeny of the genus Lygodium (Schizaeaceae) with special reference to the biological control and host range testing of Lygodium microphyllum. Biological Control 45:308318.

Mehltreter, K., Walker, L.R., and Sharpe, J.M. (eds.) 2010. Fern Ecology. Cambridge University Press, New York. 
Moran, R.C. 2004. A Natural History of Ferns. Timber Press, Inc., Portland, OR.

Mueller, R.J. 1982a. Shoot morphology of the climbing fern Lygodium (Schizaeaceae): General organography, leaf initiation, and branching. Botanical Gazette 143(3):319-330.

Mueller, R.J. 1982b. Shoot ontogeny and the comparative development of the heteroblastic leaf series in Lygodium japonicum (Thunb.) SW. Botanical Gazette 143(4):424-438.

Mueller, R.J. 1983. Indeterminate growth and ramification of the climbing leaves of Lygodium japonicum (Schizaeaceae). American Journal of Botany 70(5):682-690.

Nauman, C.E., and Austin, D.F. 1978. Spread of the exotic fern Lygodium microphyllum in Florida. American Fern Journal 68(3):65-66.

Nelson, G. 2000. The Ferns of Florida. Pineapple Press, Inc., Sarasota, FL.

Osborne, T.Z., Reddy, K.R., and Compitello, R. 2010. Effects of fire as a management tool on water quality and evaluation of effectiveness in deterrence of invasive/exotic vegetation. Final Report. Wetland Biogeochemistry Laboratory, IFAS/UFL.

OTA, 1993. Harmful Non-Indigenous Species in the United States. Office of Technology Assessment, United States Congress, Washington, DC.

Pemberton, R.W. 1998. The potential of biological control for the management of Old World climbing fern (Lygodium microphyllum), an invasive weed in Florida. American Fern Journal 84(1):76-82.

Pemberton, R.W., and Ferriter, A., 1998. Old World climbing fern (Lygodium microphyllum), a dangerous invasive weed in Florida. American Fern Journal 88:165-175.

Philippi, T.E, and Richards, J.H. 2007. Hydrologic constraints on establishment of Lygodium microphyllum. Critical System Studies Initiative, Everglades National Park Final Report. 25 pp.

Pimentel, D., Larch, L., Zuniga, R., and Morrison, D. 2000. Environmental and economic costs associated with non-indigenous species in the United States. BioScience 50(1):53-65.

Pimentel, D., Zuniga, R., and Morrison, D. 2005. Update on the environmental and economic costs associated with alien-invasive species in the United States. Ecological Economics 52:273-288.

R Core Team. 2014. R: A language and environment for statistical computing. R Foundation for Statistical Computing, Vienna, Austria. ISBN 3-900051-07-0, URL http://www.R-project.org/ 
Ranal, M.A. 1999. Effects of temperature on spore germination in some fern species from semideciduous mesophytic forest. American Fern Journal 89(2): 149-158.

Rayamajhi, M.B., Pemberton, R.W., Van, T.K., and Pratt, P.D. 2005. First report of infection of Lygodium microphyllum by Puccinia lygodii, a potential biocontrol agent of an invasive fern in Florida. Plant Disease 89:110

Rodgers, L., Black, D., Bodle, M., and Laroche, F. 2010. Chapter 9: Status of nonindigenous species in the South Florida environment. Pp 9-1 - 7-64, In 2010 South Florida Environmental Report. West Palm Beach, FL. 64 pp. Available online at http://www.sfwmd.gov/portal/page/portal/pg_grp_sfwmd_sfer/portlet_sfer/tab223 6037/2010\%20report/v1/chapters/v1_ch9.pdf

Rodgers, L., Black, D., Bodle, M., and Laroche, F. 2014. Chapter 7: Status of nonindigenous species. Pp 7-1 - 7-53, In 2014 South Florida Environmental Report. West Palm Beach, FL. 53 pp. Available online at http://www.sfwmd.gov/portal/page/portal/pg_grp_sfwmd_sfer/portlet_prevreport/ 2014_sfer/v1/chapters/v1_ch7.pdf. Accessed 24 April 2015.

Simberloff, D. 2013. Invasive Species: What everyone needs to know. Oxford University Press, NY.

Slocum, M.G., Platt, W.J., Cooley, H.C. 2003. Effects of differences in prescribed fire regimes on patchiness and intensity of fires in subtropical savannas of Everglades National Park, Florida. Restoration Ecology 11(1):91-102.

Smith, A.R., Pryer, K.M., Schuettpelz, E., Korall, P., Schneider, H., and Wolf, P.G. 2006. A classification of extant ferns. Taxon 55(3):705-731.

Smith, M.C., Lake, E.C., Pratt, P.D., Boughton, A.J., and Pemberton, R.W. 2014. Current status of the biological control agent Neomusotima conspurcatalis (Lepidoptera: Crambidae), on Lygodium microphyllum (Polyodiales: Lygodiaceae) in Florida. Florida Entomologist 97(2):817-820.

Soltis, D.E., and Soltis, P.S. 1992. The Distribution of Selfing Rates in Homosporous Ferns. American Journal of Botany 79(1):97-100.

Spear, K. 15 February 2008. "Battle with a green strangler: A choking vine becomes the top enemy of Florida's natural areas.” Orlando Sentinel. Available online. Accessed 10 May 2015. http://articles.orlandosentinel.com/2008-0215/news/fern15_1_climbing-fern-trees-invasive-plants

Stocker, R.K., Miller Jr., R.E., Black, D.W., Ferriter, A.P., Thayer, D.D. 2008. Using fire and herbicide to control Lygodium microphyllum and effects on a pine flatwoods plant community in South Florida. Natural Areas Journal 28(2):144-154.

Towill, L.R. 1978. Temperature and photocontrol of Onoclea spore germination. Plant Physiology 62: 116-119. 
Tryon, A.F., and Lugardon, B. 1991. Spores of the Pteridophyta. Springer-Verlag, New York. 648 pp.

Van Loan, A.N. 2006. Aspects of the invasion and management of Japanese Climbing Fern (Lygodium japonicum) in southeastern forests. MS Thesis, University of Florida.

Vasco, A., Moran, R.C., Ambrose, B.A. 2013. The evolution, morphology, and development of fern leaves. Frontiers in Plant Science 4(345).

Volin, J.C., Lott, M.S., Muss, J.D., and Owen, D. 2004. Predicting rapid invasion of the Florida Everglades by Old World Climbing Fern (Lygodium microphyllum). Diversity and Distributions 10:439-446.

Wally, A.L., Menges, E.S., Weekley, C.W. 2006. Comparison of three devices for estimating fire temperatures in ecological studies. Applied Vegetation Science 9:97-108.

Wang, R.L., Zheng, Z.H., Lu, J., Shao, H., Zhang, H., Su. Y.J., and Cai, Y.F. 2014. Allelopathic potential of invasive climbing fern Lygodium microphyllum against native plants and antibacterial activity of essential oils. Allelopathy Journal 33(1):97-106.

Whelan, R.J. 1995. The Ecology of Fire. Cambridge University Press: U.K.

Wikström, N., Kenrick, P., and Vogel, J.C. 2002. Schizaeaceae: a phylogenetic approach. Review of Palaeobotany and Palynology 119:35-50. 


\begin{abstract}
APPENDIX
Appendix - Additional preliminary experiment on vegetative reproduction

\section{Experiment:}

Mueller (1982a, 1983) reported leafbud outgrowth occurring both spontaneously and following damage to the leaf apex in the native range. Since these buds, as well as the leaf apex, have meristematic tissue, it might be possible for them to root and perhaps spread vegetatively along the ground, though this has not been reported for $L$. microphyllum. Several ferns (Asplenium rhizophyllous and A. ruprechtii (syn. Camptosorus rhizophyllus and C. sibiricus, respectively), Adiantum edgeworthii) spread this way by rooting wherever a frond tip touches the ground, thus forming a new individual (Moran 2004). If L. microphyllum is capable of this, then vegetative reproduction may contribute substantially to its invasive success.
\end{abstract}

Sixty greenhouse-grown sporelings were potted into individual pots and provided bamboo trellises. They were randomly assigned to one of two treatments: buried apical meristem or buried leaf bud. Climbing leaves were counted when they reached $10 \mathrm{~cm}$ in height. Relative ages for multiple leaves were determined by visual inspection of rachis texture and color, as well as height and crozier size. Treatments were applied to the first suitably long, intact climbing leaf that could be turned down and pinned without damage or undue strain, at either the most recently matured pinna or the leaf apex, depending on the randomly assigned treatment. Leaf tips or pinna were gently anchored to the soil surface with a paperclip, buried with 20-30 mL additional dirt, and watered. Leaf tips 
were anchored at $1 \mathrm{~cm}$ proximal to the tip, and last (most recently) matured pinnae were anchored just distal to the node and the resting leaf bud. All plants were allowed 53 days to grow and root, after which 30 randomly selected plants were inspected for adventitious roots by gently unearthing the pinned/buried node. Additional climbing leaves were fastened when they grew tall enough to turn down without stressing them. Additional inspections were made in the following weeks until all plants had been tallied. This experiment was conducted from March to May, 2014.

\section{Results:}

None of the buried nodes developed any roots, and most of the buried sections (tip or pinna) withered and died. The rachis of several buried climbing leaves remained alive, even with green pinnae beyond the point of burial. The portion beyond burial appeared to survive only when that portion of the climbing leaf remained above (not touching) the soil surface. Many of these plants sprouted new climbing leaves from the original rhizome, regardless of the treatment to older climbing leaves. Some of these new climbing leaves were pinned or buried after previous leaves were treated (pinned) and allowed up to 11 additional weeks to root. No roots were seen on any of these, although several climbing leaves replaced themselves from the next proximal resting leaf bud, aborting the buried section and (usually) beyond. From the experiment, noting the regular watering, stable (warm and humid) conditions, and relatively nutrient poor soil, it does not appear that L. microphyllum is actually able to produce roots (and thus no rhizome) from its resting leaf buds, nor leaf apices, at least in small leaves produced soon after the juvenile phase. 